\title{
The Examples of Traditional Folk Beliefs and Practices in Denizli, Kale-Davaz
}

Harun AKÇAM*, Serkan KÖSE**, Hüseyin KARAKAYA ***

* İstanbul Arel Üniversitesi, **Nevşehir Hacı Bektaş Veli Üniversitesi, E-mail: h.akcamm@gmail.com*, serkankose@nevsehir.edu.tr**

Copyright (C) 2015 Harun AKÇAM, Serkan KÖSE, Hüseyin KARAKAYA. This is an open access article distributed under the Eurasian Academy of Sciences License, which permits unrestricted use, distribution, and reproduction in any medium, provided the original work is properly cited.

\begin{abstract}
"Gök Tanrı" religion has a great importance, where accepting and appropriating Islam of Old Turks. But Turks, didn't give up completely the old beliefs and traditions with the Islam. Today, researchers have accepted that Turks have been continious shaping with Islam some of beliefs in Middle Asia. Elements of belief in the Middle Asia are living in the common cultural memory of society. Today's the basis of folk beliefs and personalities have been called as "veli, eren, dede, baba" with Islam in Anatolia are based on system of belief preIslamic. In this notice, it have been examined that from beliefs of folk and consist of around the tombs in Kale-Davaz town of Denizli. Datas of the study have been obtained from collected works in Kale-Davaz town and its villages. Each element of belief is analyzed by considered social and cultural context from theory and methods of folklore.
\end{abstract}

Keywords: Kale-Davaz town, Folk beliefs, tombs, veli-eren, cultural memory, social and cultural context.

\section{Geleneksel Halk İnanç ve Uygulamaları Açısından Denizli Kale-Davaz Örneği}

\section{ÖZET}

Eski Türklerin İslamiyet'i kabul etmelerinde ve benimsemelerinde "Gök Tanrı" inancının yeri büyüktür. Ancak Türkler, İslamiyet'le birlikte eski inanç ve geleneklerini tamamen bırakmamışlardır. Bugün, araştırıcılar Türklerin, Orta Asya'daki bazı inançlarını İslamiyet ile şekillendirerek devam ettirdiklerini kabul etmektedirler. Orta Asya'daki inanç öğeleri, toplumun ortak kültürel belleğinde yaşamaktadır. Günümüz halk inançlarının ve Anadolu'da İslamiyet'le birlikte "veli, eren, dede, baba" olarak adlandırılan şahsiyetlerin temeli İslamiyet öncesi inanç sistemine dayanmaktadır. Bu bildiride, Denizli'nin Kale-Davaz ilçesinde tespit edilen halk inançlarından ve türbeler etrafında oluşan birtakım inanışlardan bahsedilecektir. Çalışmadaki veriler, Kale-Davaz ve köylerinde yapılan derleme çalışmalarından elde edilmiştir. Her inanç unsuru, halkbilgisi kuram ve yöntemlerinden sosyal ve kültürel bağlam göz önünde bulundurularak analiz edilmiştir.

Anahtar Kelimeler: Kale-Davaz, Halk inancı, türbeler, veli-eren, kültürel bellek, sosyal ve kültürel bağlam. 
21. yüzyılın küreselleşen dünyasında kitle iletişim araçlarının yaygınlaşması, teknolojinin gelişmesi gibi etkenler toplumsal, siyasal, ekonomik ve kültürel birtakım değişimlerin yaşanmasına sebep olmuştur. $\mathrm{Bu}$ değişimler bir yandan kültürün "ulusaldan evrensele" yayılmasını hızlandırırken diğer yandan "tek tipleşme" sorununu ortaya çıkarmıştır. Bu bağlamda, kültürlerin tek tipleşmesini önlemek, var olan kültür değerlerini ulusaldan evrensele yaymak ve kimlikli bir ulus olmak için "kültürün korunması, yaşatılması ve gelecek kuşaklara aktarılması" önemlidir.

Kültürel oluşumların merkezinde "inanç" unsuru bulunmaktadır. İnanılan şeyler, bir döngü içerisinde bulunan sosyal hayatta yeni şartlara uyuyorsa kültürel öğe devam ediyor demektir. İnanç kavramı, sözlük anlamı olarak "kişi veya toplum tarafından, bir düşüncenin, bir olgunun, bir nesnenin, bir varlığın gerçek olduğunun kabul edilmesi" (Çobanoğlu, 2003: 11) demektir. Halkbilim açısından düşünüldüğünde ise inanç kavramı şu şekilde tanımlanabilir: "Belli bir toplumun eski dinlerinden miras alıp kendi çağının şartlarına uygulayarak yaşattığ 1 yeni dininde, yaşam şartlarının gerektirdiğince yeni biçimler, yeni içerikler ve anlatışlarla oluşturulan" (Boratav, 1997: 7) kabullerdir. Bazı inançlar "töreler, törenler ve büyü niteliğinde işlemlerle bir bütün halinde biçimlenir" (Boratav, 1997: 9) ve "uygulama" denilen pratiklere dökülür. İnançlar ve inançlara bağlı olarak gelişen uygulamalar, belleğin iletici ve tekrarlayıcı rolleri yardımıyla, süreklilik gösterir ve bunun sonucunda da gelenekselleşir. Geleneksel halk inançları ve uygulamalar, zihinsel kodlara işlenerek toplumsal bellekte yer edinir. Toplumların ortak belleğinde yer edinmiş olan geleneksel inançlar ve uygulamalar, sosyal yapıda, sözlü bir "anayasa" niteliğindedir. Yani, "sosyal eleştiri ve denetim mekanizması" (Eker, 2010: 394) işlevi üstlenerek, toplumsal ilişkileri düzenlemektedir.

Geleneksel inanç ve uygulamalar, Türk kültür yapısı içinde, sosyal hayata getirdiği bir takım düzenlemeler sebebiyle büyük önem taşımaktadır. Bu çalışmada, Kale-Davaz bölgesinde görülen inanç ve uygulamaların, Türk kültür coğrafyasının farklı dönem ve bölgelerinde görülen inanç ve uygulamalarla olan ilişkisi sorgulanacak ve elde edilen veriler Türk Dünyasındaki benzerlikleriyle örneklendirilecektir. Bu düşünceler 1şığında Kale-Davaz bölgesinde görülen inanç ve uygulamaları "Türbeler etrafında oluşan inanç ve uygulamalar", "Doğum-evlenme ve ölümle ilgili inanç ve uygulamalar" ve son olarak "Günlük hayatta görülen inanç ve uygulamalar” başlıkları etrafında sıralamanın uygun olacağı düşünülmüştür.

\section{Kale-Davaz Bölgesindeki Türbeler ve Etrafında Oluşan İnanç ve Uygulamalar}

İslamiyet'ten önceki dönemde adları kam, baksı, bahşı, oyun, baba veya ata olarak adlandırılan şahsiyetler, İslamiyet'ten sonra veli-eren-evliya gibi adlarla ifade edilmiştir (Çetin, 2007: 70). Anadolu'nun Türkleşmesi ve İslamlaşmasında önemli bir rol üstlenen (Barkan, 1942) bu şahsiyetlerin halk tabakasında birtakım kerametlerinin olduğuna inanılması ve kutsal kişiler, Allah'a yakın kişiler olarak ifade bulması söz konusudur. Türbeler; hastalıklar, çaresizlikler ve sıkıntılar içerisindeki insanlar için bir sığınak ve hatta birçok durumda son bir çaredir. Bu ziyaret yerleri, kuraklık, sünnet, evlenme, çocuk sahibi olma gibi hayatın kritik safhaları ve anları için de bir güven ve ümit kaynağıdır. Uzun ayrılıklar, insan hayatı bakımından mühim geçitler ve sınavlar, her çeşit istek, türbeler aracılığıyla korunmaya, beklentiye ve huzura kavuşur (Günay vd, 2001: 105). Türbeler, toplumun kültürel belleğinde inanç odaklı olarak ortaya çıkmıştır. İnanç odaklı olmasından dolayıdır ki toplumsal bellekte "hatırlanması, korunması, yaşatılması" ve günümüze kadar "aktarılması" daha kolay olmuştur. 
Kale-Davaz bölgesinde dikkat çeken en önemli inanç unsuru türbe ve ziyaret yerleridir. Halkbilgisinin en önemli yazılı kaynaklarından olan seyahatnamelerde Kale-Davaz bölgesinde "Horasan erenleri" olarak adlandırılan bu şahıslarla ilgili bilgiler bulunmaktadır. Bunlardan Evliya Çelebi Seyahatnamesi'nde, Kale'nin İç Kale ve Dış Kale olarak iki bölümden oluştuğu ve Dış Kale'de Karaca Ahmed Sultan, Sarı Baba Sultan, Ilkınlı Sultan, Kepez Dede, Ali Balı Dede, Gülüm Dede gibi evliyaların adları geçmektedir. (Kahraman, 9/117: 2013)

Seyahatname de görüldüğü üzere Kale-Davaz bölgesi Anadolu'nun Türkleşme ve İslamlaşmaya başladığı ilk zamanlardan itibaren dervişlerin yaygın bir şekilde bulunduğu yerleşim yerlerindendir. Günümüzde ise Kale-Davaz'da altı tane türbeden söz edilebilir. Bunlardan Kuş Dede, Arap Apıştı ve Yaren Baba (Kurubağlık) adı verilen türbeler yüksek bir tepede iken, Koyun Baba ve Yaren Baba (Kale-Merkez) Türbeleri düzlükte yer almaktadır. Bunların yanında Dırbıllı Dede olarak adlandırılan bir zatın da olduğu söylenmektedir, ancak türbesinin nerede olduğuyla ilgili herhangi bir bilgi bulunmamaktadır.

\subsection{Kuş Dede Türbesi}

Yeniköy'de yüksek bir dağın zirvesinde, Kuş Dede adı verilen bir türbe bulunmaktadır. Kuş Dede adıyla anılan ve kendisine türbe yapılan bu zatın ne zaman yaşadığı ve neden Kuş Dede adıyla anıldığ 1 hakkında köyde yaşayanların bilgisi yoktur. Kuş Dede hakkında köylülerce bilinen bir tek olağanüstü olay şu şekildedir: Kuş Dede'nin Türbesi'nin bulunduğu dağın karşısındaki Karadağ'da "Kara Dede" adlı bir zatın türbesi vardır. Kuş Dede ve Kara Dede'nin özellikle Perşembeyi Cumaya bağlayan kimi gecelerde bir 1ş1k huzmesi ile birbirlerini ziyaret ettiklerine şahit olunmuştur. (Fatma Kökçıkaran, Kişisel Görüşme, Kasım 2011)

Tespitlerden hareketle öncelikle veli-eren olarak anlamlandırılan "Kuş Dede"nin neden "Kuş Dede" olarak adlandırıldığıyla ilgili düşünceleri söylemek yerinde olacaktır. Eski Türklerin inançlarında kuş, şamanın ayin sırasında üzerindeki elbiselerinde kullanılan bir figürdür. Kuş giysisi trans halinde öbür dünyaya yolculuk için kullanılmıştır (Eliade, 1999: 186-187). Ayrıca Anadolu'daki halk anlatılarında "kuş donuna girme" motifi yaygındır. Hacı Bektaş Veli, Ahmet Yesevi tarafından icazetle Rum'a halife gönderildiğinde, bir güvercin şeklinde Sulucakaraöyük'e inmiş ve bir taşın üstüne konmuştur. Yine Hacı Bektaş halifelerinden olan Sarı İsmail, sarı bir doğan şeklinde Tavas'a gitmiştir (Ocak, 2010: 219220). Kuşun Türk kültüründeki bu işlevi iletişimi sağlaması olarak açıklanabilir. Bu bağlamda adı geçen Dede'nin "kuş" olarak adlandırılması kanaatimizce ortak kültürel bellekte kuşun iletici-haberci işlevinden kaynaklanmasıdır. Dolayısıyla Kuş Dede yöre halkının dileklerini Tanrı'ya ulaştıran bir araç olarak karşımıza çıkar. Adlandırma konusundaki diğer husus ise, Anadolu'nun birçok yerinde görüldüğü gibi Allah'a yakın olduğuna inanılan şahsiyetlerin “dede-baba” gibi adlarla ifade edilmesidir. Destanlarda, masallarda, halk hikâyelerinde zor zamanda kahramana yardım eden "aksakallı dedeler"in varlığından söz edilebilir. Bunun Türk sözlü kültüründeki en göze çarpan örneği olarak "Dede Korkut" gösterilebilir. Dede Korkut'un "Oğuzun ol kişi tamam bilicisi”" (Ergin, 2004: 73) olması, onun Allah'a yakın ve tecrübeli bilgin olarak saygı duyulan kişi olmasını beraberinde getirmiştir. Bu bağlamda bir şahsın dini-sihri birtakım özellikleri olduğuna inanılmasından dolayı "Kuş Dede" ismiyle zikredildiği söylenebilir.

Köy halkı Kuş Dede Türbesi'ne her yılın ağustos ayında çıkmaktadır. Köy halkının türbede namaz kılma, kurban kesme, adak adama gibi uygulamaları yerine getirmesi Kuş Dede'nin birleştirici fonksiyonunu ortaya koymaktadır. Ayrıca köyde bulunan her sülalenin 
türbe etrafında belirlenmiş bir yeri vardır. Bu uygulamanın, Türk kültüründe belirli bir düzen içerisinde yerleşmeyi ifade eden "orun” kavramılla ilişkili olduğu düşünülebilir.

Türbe etrafinda tespit edilen bir başka uygulama ise, ağaçlara bez bağlanması ve türbenin üstüne buğday atılmasıdır. Ağaca bez bağlama geleneği bilindiği üzere eski Türk inanç sistemiyle ilgilidir. Eski Türk inancında ağaç, Tanrı'yı sembolize eden, Tanrı kutunun kaynağı olarak görülmüştür (Ergun, 2004: 16). Abdülkadir İnan, eski Türk inancında ağaçlara ve şaman davuluna bağlanan paçavraların (yalma) olduğunu ifade etmiştir (İnan, 2006: 98). Dolayısıyla eski Türk inancının izleri Kuş Dede Türbesinde de görülmektedir. Ayrıca mezarın üstüne buğday atılması, kuşların yemesi içindir ve buğdayın bolluk ve bereketi simgelemesiyle açıklanabilir.

\subsection{Arap Apıştı Türbesi}

Kale İnceğiz Köyü’nün etrafındaki bir tepede “Arap Apıştı” denilen bir türbe bulunmaktadır. Arap Apıştı Türbesi hakkında köylülerce anlatılan bir efsane vardır. Bu efsane şu şekildedir: Köyün olduğu bölgede gezen bir Yörük Beyi, Arap'a susadığını söyler. Arap da köyün yakınındaki vadiden su getirmeye gider. Arap'ın uzak mesafede olan suyu kısa zamanda getirmesi karşısında Yörük Beyi meraklanır ve Arap'ı bir daha su almaya giderken takip eder. Ermiş olan Arap vadiye geldiğinde bir dev'e dönüşerek suyu almaktadır. Yörük Beyinin, Arap'ın vadiden deve dönüşerek suyu aldığını görmesi üzerine sırrın ifşa olmasından dolayı Arap ölmüştür (Kamil Pekçok, Kişisel Görüşme, Kasım 2011)

Yukarıda bahsettiğimiz üzere, Arap Apıștı Türbesi etrafında şekillenmiş bir efsane vardır. Araştırıcılara göre, efsanelerin işlevlerinden birisi "bir toplum için önemli olan olay, durum, varlık ve sosyal kurumların oluşum nedenlerine açıklama getirme"dir (Oğuz vd, 2010: 143). Dolayısıyla halkın veli-eren olarak adlandırılan şahsın etrafında bir anlatı kurgulamasının sebebi, türbede yattığına inanılan şahsiyetin dini-sihri birtakım özellikleri olduğuna inanmasıdır.

Arap'ın suyu alırken ayaklarını ve ellerini dayadığı yerler köylüler tarafından kutsal kabul edilmiştir. Sol elinin ve sol ayağının bulunduğu yerlerde tekke ve türbe bulunmaktadır. Başının ise kıbleye doğru olduğu ve suyun içinde kaldığına inanılmaktadır. Sağ ayak ve sağ el vadinin karşı kıyısında bulunduğu için bunlarla ilgili herhangi bir bilgi yoktur. Arap su alırken bacaklarını açıp çömeldiği için "Arap Apıştı" adını almıştır.

Arap Apıştı türbesinde köylüler bahar aylarında yağmur duasına çıkmaktadır. Yağmurun, dua yapıldıktan belli bir süre sonra bu tepenin olduğu yerden geldiği söylenmektedir. Bununla birlikte çevre köylerden insanlara haber vermek için silah atılmaktadır. Burada köylüler kurban kesip evlerinde yaptıkları yemekleri yemektedirler.

Yağmur yağdırma törenleri, havaların kurak gittiği dönemlerde geciken yağmuru yağdırmak ve böylelikle toprağı canlandırarak bereketi artırmak amacıyla düzenlenen dinsel ve büyüsel uygulamaları içine alır. Yağmur duasına mümkün olduğu kadar kalabalık gruplarla çıkılır. İnceğiz Köyü halkı da yağmur duası için yüksek bir mevkide olan Arap Apıştı Türbesi'ne çıkarak dua etmektedirler. Ayrıca, yöre halkı, bu ritüeli gerçekleştirdiğinde, çevreye yağmur duası olduğunu haber vermek için silah attığını söylemektedir. Ancak Orhan Acıpayamlı'ya göre bu uygulamanın altında yatan asıl sebep şudur: "Gürültü, şüphesiz, gök gürültüsünü canlandırmak amacıyla yapılmaktadır. Böylelikle yağmur nasıl gök gürültüsünü müteakip meydana geliyorsa, gök gürültüsünü taklit eden seslerden sonra da yağmurun yağacağına inanılmaktadır" (Acıpayamlı, 1963: 22). Yaşar Kalafat'a göre ise; "Şüphesiz, sesin bizzat kendisi bir inanç değildir. Şiddetli ses ve gürültü; zararlı olduğuna inanılan 
güçlerden kurtulma ve kurtarmada uygulanan bir dini pratiktir” (Kalafat, 2009; 117). Her iki görüş de Anadolu coğrafyasında yaygın uygulama alanı bulmuştur. Dolayısıyla havaya silah atmak hem gök gürültüsünü taklit etmekle hem de kötü ruhların kovulmasını sağlamakla açıklanabilir.

Arap Apıştı Türbesi'nin etrafinda oluşmuş bir diğer uygulama ise, kurban kesmedir. $\mathrm{Bu}$ kurban koyun, keçi gibi hayvanlardan seçilir. Çocuğu ölen kişilerin türbeye gelip adak adadıkları ve bu sayede bir daha doğacak çocuklarının sağlıklı olacağına inanılır. Eski Türklerde Şamanların, kurbansız ayin yapmadıkları bilinmektedir. Her ayin için kanlı veya kansız kurban bulunması gerekmektedir (İnan, 2006: 99).

\subsection{Koyun Baba Türbesi}

Kaynaklara göre Anadolu'nun farklı yerlerinde ve Balkanlarda da Koyun Baba adıyla anılan Veli-erenlerin olduğu söylenmektedir (Ocak, 2010: 48, Önal, 2000: 42). Öcal Oğuz, "Çok Mekanlı ve/veya Çok Mezarlı Anlatı Kahramanları: Yunus Emre" adlı makalesinde, "Yunus Emre'nin sözlü geleneğin ve sözel belleğin" (Oğuz, 2011: 5) içinde yer aldığını söylemiştir. Bu bağlamda Koyun Baba'nın da Yunus Emre gibi sözel belleğin ürünü olduğu düşünülebilir. Kale-Davaz'ın Çamlarca köyünde de Koyun Baba Türbesi bulunmaktadır. Koyun Baba halk arasında keramet sahibi birisi olarak bilinir ve onunla ilgili birtakım inanışlar vardır. Koyun Baba bir dua ile dağdaki taşları koyuna ve yine dua ederek koyunları da taşa çevirmiştir. Koyun Baba'nın bir başka kerameti şudur: Koyun Baba, Cuma namazını kılmak için Karaköy'e gider. Buradaki halk Koyun Baba'dan bir keramet göstermesini ister. $\mathrm{O}$ da dut ağacından yapılmış olan bastonunu caminin önüne diker ve "Ey dut ben camiden çıkana kadar tut" der. Köy halkı camiden çıktıktan sonra bastonun yeşerdiğini görür. Bu dut ağacı hala Karaköy'deki caminin önünde bulunmaktadır. Bu bağlamda Koyun Baba'yla ilgili anlatılan kerameti açıklamak için eski Türk inancında ağacın işlevinden bahsetmek yerinde olacaktır. Türk kültüründe ve evrensel kültürde "Kozmik Ağaç (Dünya Ağacı, Hayat Ağac1)", "Tanrı'yla İletişim Aracı Olarak Ağaç", "Şeytan ya da Kötü Ruhları Kovma Törenlerinde Ağaç", "Tabiat Olaylarını Yönlendirme Törenlerinde Ağaç", "Defin Törenlerinde Ağaç", "Bereketi Arttırmaya Yönelik Mevsimlik Törenlerde Ağaç", "Sığınılan Tanrı'yı Temsil Eden Gölgeli Ağaç" vb. ağaçlarla ilgili birçok inanış bulunmaktadır (Ergun, 2004). Koyun Baba'nın Cuma namazından sonra bastonunun yeşerip ağaç olması Anadolu ve Orta Asya'daki farklı veli-erenlerde de görülmektedir. Ahmet Yesevî'nin ağaç atıp yeşertmesi, Geyikli Baba'nın Orhan Gazi'nin bahçesine kavak dikip yeşertmesi (Ögel, 1995: 469) örnek olarak verilebilir. Ayrıca, İzmir Kemalpaşa'da "Hamza Baba" hakkında anlatılan bir keramet vardır. Bu keramet, Hamza Baba'nın toprağa asma dalları sokması ve arkasını döndüğünde asmaların üzüm vermiş olmasıdır (Mete, 1996: 122). Görülüyor ki, Türk kültürel belleğine ilişkin temel kodlardan biri olan "ağaç" İslamiyet'le birlikte devamlılık göstermiştir.

Veli-erenler, topluma savaş ve felaket gibi zor zamanlarda yardım ederek kurtarıcılık işlevini yerine getirmektedirler. Hatta bu şahsiyetlerin bizzat savaşlara katılarak bu işlevi yerine getirdiğine dair inançlar vardır. Bu durum Koyun Baba'yla ilgili anlatılan bir inanışta aynen geçmektedir. Yöre halkı Koyun Baba'nın türbesinde bulunan topuzların ve sancağının Kıbrıs Barış Harekâtı sırasında kaybolduğunu görmüştür. Savaş bittikten sonra topuzların ve sancağın yerine geldiğini ve üzerinde kan izleri olduğunu fark eden halk, Koyun Baba'nın Kıbrıs Barış Harekâtı'na katıldığına inanmaktadır. Dolayısıyla toplum, kendisine yardım edeceğine inandığı birtakım manevi güçleri olan şahsiyetlere zor zamanlarında başvurmuşlardır. Bununla birlikte hastalıklara şifa çocuksuzluğa çare aramak için de türbelerin ziyaret edildiği bilinmektedir. Çocuğu olmayan kadınlar, Koyun Baba Türbesi’ne 
gelerek boyunlarına "beş yüzlük" adı verilen tespihi takarlar. Ayrıca çocuğu olmayan kadınlar türbe etrafında dolanırlar. Daha sonra türbenin içindeki kilimleri kaldırır ve altından çıkan böceği yerler. Bu uygulamalarla çocuğu olmayan kadınların çocuğu olacağına inanılmaktadır. Koyun Baba'yı hastalıktan kurtulmak için de ziyaret edildiği tespit edilmiştir. Türbenin yirmi metre önünde kaya dibinde bulunan bir oyuğa el sokulduğunda siğil hastalığının iyileşeceğine inanılmaktadır.

Halk arasında, Koyun Baba Türbesi'nin etrafında bulunan bitki ve ağaçlardan alındığında alan kişinin başına kötülük geleceğine dair inanış vardır. Kaynak kişiler bir kişinin türbe etrafındaki piynarları (dikenli yaprakları olan bir tür ağaç) eşeğine yedirdikten sonra eşeğin öldüğünü söylemektedirler. Toplumun kutsal olarak gördüğü bir şahsiyetin aynı zamanda mekânı da kutsal kabul edilir. Toplumun ortak algısında kutsallık kazanmış olan bu mekândan alınan herhangi bir şeyin "yasaklanmış" olduğu inancı toplumsal ahlaka yapılan bir vurgudur.

Türbe etrafında halk kurban keser ve adak adar. Ancak bu kurbanlık ve adaklik hayvanlar koyun değil; keçi ya da büyük baş bir hayvandır.

\subsection{Yaren Baba Türbesi}

Kale'de iki tane Yaren Baba adında veli-eren bulunmaktadır. Bunlardan birincisi Kale merkezde bulunan Yaren Baba'dır. Halk arasında Yaren Baba'yla ilgili birtakım inanışlar vardır. Bir kişi, Ramazan ayında, Yaren Baba türbesinin ışığının çok parlak bir şekilde yandığını görmüştür ve bunun üzerine türbenin olduğu yere gitmiştir. Türbenin önünde üç saf haline dizilmiş kişilerin namaz kıldığını görmüştür. Türbeye biraz daha yaklaştıktan sonra içeriye girmek istemiş ancak girememiştir. $O$ esnada 1şığın kaybolduğunu gören kişi kulübesine saklanmıştır. Bir müddet sonra namazı kıldıran zat kulübenin kapısını çalmış ve "Evlat sen taharetsiz ve abdestsiz geldiğin için biz seni içeri almadık" diyerek kaybolmuştur. $\mathrm{Bu}$ anlatı, dini hayatta yapılması ya da yapılmaması gereken şeylerin ne olduğu konusunda bir iletişim aracı olarak karşımıza çıkar.

Halk arasında Dırbıllı Dede olarak bilinen ancak mezarının nerede olduğu bilinmeyen bir veli-eren de vardır. Bu eren Koyun Baba ve Yaren Baba'yla önemli gün ve gecelerde buluşmaktadır. Anlatılanlara göre, Yaren Baba; Koyun Baba ve Dırbıllı Dede'yi yanına çağırır. Diğer iki eren ise, Yaren Baba'nın yanlarına gelmesini ister. Bir yaşlı kadın ise geceleyin bahçesini sularken bu üç veli-eren'in birbirlerine seslenmelerini duyar. Daha sonra Yaren Baba beyaz bir atla diğer iki eren'in yanına gitmek için yola çıkar. Yaşlı kadın da Yaren Baba'yı görür ve O'nu durdurarak atının başını tutar. Yaren Baba da bunun üzerine yaşlı kadına "Ne istiyorsun? Dünyalık mı ahiretlik mi?" diye sorar. Yaşlı kadın da "Ne yapacağım bu yaştan sonra dünyalığı ahiretlik isterim" der. Yaren Baba da "Hadi iki cihanda da yüzün ak olsun, koy ver atın başını" diye cevap verir. Anlatılanlara göre yaşlı kadının sonraki hayatı boyunca hiç tükenmeyen kışlık erzakı olmuştur. (İsmail Yarımca, Kişisel Görüşme, Kasım 2011) Bu anlatıda Yaren Baba'nın "beyaz at"la anlamlandırılması, Türk anlatılarında Köroğlu'nun “Kırat”la, Hızır'ın “Ak Boz At”la, Manas'ın “Ak Kula At”la ifade edilmesinden pek farklı olmasa gerek. Ayrıca, topluma dünya nimetlerine hürmet etmeme yönünde bir öğüt verme görülmektedir.

Yukarıda bahsettiğimiz gibi Kale'de bir diğer Yaren Baba Türbesi ise Kurubağlık köyünde bulunmaktadır. Bu türbe, Kurubağlık köyünün dışında yüksekçe bir tepededir. Diğer erenlerde olduğu gibi Yaren Baba etrafinda da oluşmuş inanışlar vardır. Kurubağlık köyünde bir âlim köyde kolera (kuleyli) hastalığının yayıldığını görür. Yaren Baba bu hastalığın 
ölümle sonuçlanacağını söyler. Köyden geçen bir dereyi Yaren Baba entarisini gererek ikiye bölmüş ve derenin köyün aşağı kısımlarında tekrar birleşmesini sağlamıştır. Yaren Baba'nın bu kerameti sayesinde köy hastalıktan kurtulmuştur. (Emin Çakmakçı, Kişisel Görüşme, Kasim 2011)

Yaren Baba Türbesi'nin önünden geçen bir maden işçisi türbeye dönerek "Sen Kimsin" gibi alaylı sözler söyler. Bunun üzerine bu kişi o gece rüyasında arkasında binlerce kişilik ordusu olan Yaren Baba'nın kendisini kırbaçladığını ve sabah kalktığında ise kırbaç izlerinin hala sırtında olduğunu görür. Veli-erenlerin kendisine karşı kötü ya da aşağılayıcı davranışlarda bulunanları "cezalandırma" işlevi olduğu görülmektedir. Otman Baba kendisine kötü davranan Fatih'e kızdığı için elindeki değneği yere vurduğunda, gökyüzü bulutlanmış, aniden yağmur başlamış ve ortalığı sel götürmüştür (Ocak, 2010: 162). Dolayısıyla "cezalandırma" işleviyle veli-erenler ve onlar etrafında anlatılan kıssalar, toplumsal bir öğüt niteliği taşımakla birlikte toplumsal düzeni de sağlar.

Kurubağlık’taki Yaren Baba Türbesi’nin üzerine halk tarafından piynar ağacinın dalları konulmuştur. Kanaatimizce, bu olay ağaç kültünün günümüze yansıması olarak görülmektedir. Dolayısıyla toplumun ortak belleğinde, Atalara duyulan saygı ve ağaca atfedilen kutsallık Yaren Baba Türbesinde bir arada görülmektedir.

\section{Doğumla İlgili İnanç ve Uygulamalar:}

2.1. Doğum Öncesi: Yukarıda da bahsettiğimiz üzere, Kale-Davaz Bölgesi’nde Anadolu'nun diğer bölgelerinde olduğu gibi çocuğu olmayan kadınların türbe ziyaretleri neticesindeki uygulamalarla çocuğu olacağına inanılmaktadır.

Anadolu'nun birçok yerinde hamile kadınların "aş ermesi" durumu söz konusudur. Kale-Davaz bölgesinde de hamile kadınlarda bu durum görülmektedir. Eğer hamile kadının canı ekşi yiyecekler istiyorsa doğacak çocuğun kız olacağı, tatlı yiyecekler istiyorsa doğacak çocuğun erkek olacağı inancı vardır. Ayrıca, hamile kadının baykuş, domuz gibi hayvanlara bakması hoş karşılanmaz. İnanca göre, hamile kadın, tavşan ve balık eti yemez. Eğer tavşan eti yerse dünyaya gelecek çocuğun yırtık dudaklı; balık eti yerse çocuğun balık iskeletli olacağı inancı vardır. Bunlardan başka hamile kadının ölü evine gitmesi de hamilelik sırasındaki yasaklardan birisidir. Ayrıca yeni evlilerin yatak odasında, karyola üzerinde erkek çocuk yuvarlattırılır. Bu durum erkek çocuk doğması adına bir temennidir. (Fatma Kökçıkaran, Kişisel Görüşme, Kasım 2011)

2.2. Doğum Sonrası: Doğum yapan iki kadının birbirleriyle görüşmesi yasaktır. Eğer bilmeden karşılaşırlarsa da iki kadın birbirleriyle mavi boncuklarını değişir. Bilindiği üzere mavi boncuk Türk inançları içinde nazardan, kötü ruhlardan korunmak için kullanılır. Loğusa kadınların birbirlerini gördüklerinde mavi boncuklarını değişmelerinin sebebi ise çocuğa ve anneye musallat olan "al bastı-al karısı" olarak bilinen kötü ruhlardan koruma olarak düşünülebilir.

Bebek doğduktan kısa bir süre sonra düşen göbek bağı, bebek büyüdükten sonra hangi mesleği icra etmesi isteniyorsa o mekânın bahçesine gömülür. Örneğin; okuması isteniyorsa okul bahçesine, imam olması isteniyorsa cami bahçesine gömülür. Bu uygulamanın eski Türk düşüncesinde çocukları koruyan ruh olan Umay Ana ile bir ilişkisi olduğu söylenebilir. Göbek bağı yeni doğan çocuğa bağlı olup onu ana rahminde beslediği gibi, dünya hayatının ilk günlerinde de besler, onu büyülerden ve hastalıklardan korur. Bu durumda göbek bağı Eski ve Orta çağda çocukların ve yeni doğanların koruyucusu Ana Tanrı "Umay”ın görevini üstlenir (Bingöl, 1997: 119). Günümüz tıp dünyasında göbek bağı "kök hücre" tedavilerinde 
kullanılmaktadır. Kök hücre tedavisiyle gelecekte karşılaşılabilecek hastalıklara çare söz konusudur. Aynı zamanda Tük inanç sisteminde bahsettiğimiz uygulama da çocuğun geleceğine dair iyi bir hayat sürebilmesi inancına dayanmaktadır. Dolayısıyla her iki uygulama da gelecek kaygısına dair düşünceyi yansıtmaktadır, düşüncesindeyiz.

Bebeğin nazardan korunması için yapılan çeşitli uygulamalar vardır. İlk işlemde bir bez parçasının içine karaca susam (çörek otu), zeytin çekirdeği, susam, bir gök boncuğu konur ve bu bez parçası dikilir. Daha sonra bu bez parçası bebeğin yakasına dikilir. Bu uygulamada zeytin çekirdeğinin ve susamın kullanılma sebebi neslin devamlılığını sağlamak, gök boncuğunun kullanılma sebebi ise nazardan korunmaktır.

İkinci işlem ise "diş tuzlaması" denilen işlemdir. Bebeğin dişi ilk çıktığg zaman, evde bulunan nohut, buğday ve darı kaynatılır. Kaynatıldıktan sonra bunlardan birer tutam alınır ve bebeğin başından aşağıya serpilir. Serpme sonucunda bebeğin başı üzerinde kalanlar, bir ipe dizilir ve bebeğin yakasına asılır. Bunların bebeği nazardan koruduğuna inanılır. Ayrıca, bir kazanda kaynatılan nohut, buğday ve darı komşu ve akrabalara dağıtılır.

Üçüncü işlem ise bebeğin yakasına nazarlık takma ve bulunduğu ortamda üzerlik yakma işlemidir. Bebek doğduktan otuz yedi ya da otuz dokuz gün sonra (sayılar tek olmalidır) tuzlanır.

Bebek kırk günlük olunca kırk bir tane taş toplanır ve toplanan bu taşlar bir bezin içine konur. Bebek kırklanacağı zaman bu taşlar bebeğin yıkanacağı suyun içine atılır ve bebek bu suyla yıkanarak kırklanır. Bilindiği gibi, her toplumun ilkel döneminde tabiattaki her şey canlı bir varlık olarak düşünülmüş ve tabiatta birtakım gizli güçlerin bulunduğuna inanılmıştır. $\mathrm{Bu}$ inanışa göre dağlar, tepeler, ağaçlar ve kayalar hisseden, işiten, iyilik veya kötülük yapabilen varlıklardır; daha doğrusu bunları yapan onlardaki gizli güçlerdir (Ocak, 2010). Taşın bebeğin kırklanması esnasında kullanılmasının sebebi koruyucu bir ruhunun olduğu inancindan kaynaklanmış olabilir.

\section{3. Ölümle İlgili İnanç ve Uygulamalar:}

Bir kişi öldükten sonra onun "Sin Kurbanı” kesilir. Sin Kurbanı, bir kişinin öldükten sonraki ilk kurban bayramının arifesinde kesilen kurbandır. Bu kurban daha sonra adak gibi komşu ve akrabalara dağıtılır. Bu inanç İslam öncesi Türk kültüründe "atalar kültü"yle ilişkilendirilebilir. Bilindiği üzere Türkler İslamiyet'ten önce de atalarına saygı mahiyetinde mezarlarında kurban sunarlardı. İslamiyet'le birlikte bu inanç ölen kişinin günahlarının bağışlanması şeklinde düşünülebilir.

Bir kişinin ölümünden sonra akrabalarının çok ağlaması durumunda ailenin başına daha büyük bir felaketin geleceğine inanılır.

Hastanın son nefesini vermesine az bir süre kala yanında buhur yakılır. Buradaki amaç; buhur sayesinde şeytanı kaçırtmak ve hastanın kolay bir şekilde ruhunu teslim etmesini sağlamaktır. Vefat eden kişi kefenlenmeden önce de kefen buhurlanır. Cenaze evinde "buhur" yakılır ve bu koku bütün mahalleye yayılır. Bu kokunun farkına varan insanlar mahallede bir cenazenin olduğunu anlarlar. $\mathrm{Bu}$ şekilde cesedin kokmayacağı ve şeytanın ölüye yaklaşamayacağına inanılır. Kanaatimizce, bu uygulamanın sebebi olarak ölen kişinin ruhunun ş̧eytanla birlikte yeraltına değil dumanla birlikte gökyüzüne çıkması olarak düşünülebilir. Ayrıca ölünün üzerine bıçak ya da makas gibi metal eşyalar konulur. $\mathrm{Bu}$ uygulamanın görünen sebebi ölünün şişmesini engellemek olsa da altında yatan sebep eski Türklerde demire atfedilen kutsallıktır (İnan, 2006). 
Ölümden sonra önemli günlerde mezar ziyaretleri gerçekleştirilir. Bu ziyaret esnasında, mezarların başına su testisi, yaban mersini ve buğday bırakılarak dua edilir. Yukarıda bahsettiğimiz gibi, eski Türklerde atalara saygı amacıyla yapılan mezar ziyaretleri bu uygulamada da görülmektedir.

\section{Evlilikle İlgili İnanç ve Uygulamalar:}

Anadolu'nun birçok yerinde olduğu gibi Kale-Davaz bölgesinde de geline ve damada kına yakılır. Bu uygulama, gelinin damada, damadın ise geline bağlı kalmasına yönelik bir düşünceden kaynaklanır.

Gelin almaya gidilen yoldan geri dönülmez. Eğer dönülürse karı-kocanın geçiminin zorlaşacağına inanılır.

Gelin, oğlan evine geldiğinde evden ilk defa içeriye girişi sırasında kapının önüne yağ sürer ve kapıya çivi çakar. Kapı üzerine yağ sürmek evliliğin sorunsuz devam etmesi, kapıya çivi çakmak ise evliliğin daimi olması amacıyla yapılan uygulamalardır. Ayrıca gelinin ağzı dili bal gibi olsun diye, gelin eve girerken eşiğe tatlı sürülür.

Dügünden sonra gelin ve damadın başından buğday, şeker, para gibi bereketi simgeleyen yiyeceklerin atılması söz konusudur. Eski Türklerde de bu uygulamanın görüldügüünü söyleyen Abdülkadir İnan'a göre, bu uygulama, "yabancı soya mensup olan bir kızı, kocasının soyunun ataları ve koruyucu ruhları tarafından kabul edilmesi için yapılan bir kurban ayinin kalıntısıdır" (İnan, 167).

\section{Günlük Hayatta Görülen İnanç ve Uygulamalar:}

- Kapı eşiğine oturan kişiye cinlerin zarar vereceği ve o kişinin kısmetinin kapanacağı inancı görülmektedir. Bu uygulamanın Eski Türk inanç sistemiyle bir ilişkisi olduğu söylenebilir. Türk mitolojik sisteminde ev-eşik koruyucusu, Altay-Sayan Türklerinde Ülgen'in oğlu olarak şekillenmiştir. Nitekim Şor Türklerinde “Ejik Eezi” Ülgen'in oğlu olup insanların yaşadığı evi korumakla yükümlüdür."Eşik iyesi”nin eve hem bereket hem felaket getirdiği inancı vardır. Eşik, bir dünyadan diğer dünyaya giriş, dıştan içe, yabancı âlemden kendi mekânına geçiş olduğu için kutsaldır (Bayat, 2007: 268-269).

- Geceleri saç kesmek, saç taramak ve tırnak kesmek olumsuz bir hareket olarak görülmektedir. Bunun altında yatan düşünce saç ya da tırnak kesenin gece karanlıkta kendisine zarar verebileceği düşüncesidir.

- Tavşan ve baykuş uğursuzluk getiren hayvanlar olarak düşünülür. Tavşan, eski Türklerde saygı duyulan bir hayvandır. Bundan dolayıdır ki on iki hayvanlı Türk takviminde yer almıştır. Ayrıca şamanın yardımcı ruhlarından biri olduğu bilinmektedir. Daha sonra algı değişmesi sonucu olumsuz görülen hayvanlardan biri olmuştur. Bunun sebebi Hz. Hüseyin'in katilinin "tavşan donunda" görülmesi şeklinde düşünülebilir. Günümüzde baykuş uğursuzluk getiren bir hayvan olarak düşünülse de eski Türklerde şamanın en çok suretine girdiği hayvanlar arasında yer almış (Çoruhlu, 2006:157) ve "ügi-ügü-ükü-ükkü” gibi adlarla Bayat boyunun ongun kuşu (Ögel, 2003: 357) olarak karşımıza çıkmıştır.

- Gün batımından sonra komşuya acılı yemek verilmez, verilirse yemeği alan kişinin kötü bir haber duyacağına inanılır. Bu inanç eski Türk düşüncesinde Erlik'in yer altı dünyasında yaşaması ve dolayısıyla karanlık âlemin sahibi olmasının bir yansıması olarak düşünülebilir. 
• Dünyanın bir öküzün boynuzları üzerinde döndüğü ve tüylerinden birinin kımıldamasıyla depremler meydana geldiği inancı hâkimdir. Türk mitolojisinde dünya öküz veya boğanın üzerine kurulmuş olarak tasarlanmıştır. Altay’ın kuzeyindeki Teleüt Türklerine göre "Dört gök öküz, tabağa benzeyen dünyayı altına girerek değil; kenarlarına koşulmuş olarak tutuyorlardı. Öküzlerin kıpırdamalarından deprem oluyordu" (Ögel, 1995:

248).Dolayısıyla bahsettiğimiz inancın eski Türk düşüncesiyle ilişkili olduğu söylenebilir.

- Geceleyin kullanılmış su dökülmez. inanilir.

- Arife gecesi dikiş dikilmez, eğer dikilirse ölen kişilerin su testilerinin delineceğine asilir.

- Yeni yapılan evlerin saçaklarına yumurta koyulur, sarımsak ve gök boncuğu dizilerek

- Salyangoz kabuklarından yapılan nazarlığın kötülüklerden korunacağına inanılır.

- Çocuklara muska; çıtlık ağacı, çörek otu ve zeytin çekirdeğinden yapılır; yapılan muska sırtlarına asılır. Muska çıkarılırsa çocuğa nazar değeceğine inanılır.

- Bir kişi üzerine giyimli haldeyken düğme dikilmez.

- Gece aynaya bakilmaz.

• Ölen kişinin elbiseleri aile içinden birine verilmez.

- Yolculuğa çıkan kişinin ardından bir tas su dökülür.

- Tarlayı nazardan korumak için kazık üzerine konulmuş “öküz başı” dikilir.

• Evde örümceğin görülmesi misafirin geleceği şeklinde yorumlanır.

- Kabirde ölüyü gömerken küreği elden ele almamak gerekir; alınırsa o kişinin ölümünün yakın olacağına inanılır. Erken ölüm olmasın diye kürek yerden alınır.

- Kaynayan suya biçak konmaz. Nimetin bereketi kaçar.

- Lohusa kadının yanına ya da bebeğin yatağına orak ya da bıçak konur ki al basmasın diye. asilir.

- Sacayağını yatık bırakırsan iyi olmaz; o hane borçtan kurtulmaz; o nedenle sacayağı

- Zeytin ağaçları olan bahçelerde tüm zeytinler toplanmaz. Dallarda birakılanlar kuşun kurdun hakkıdır; kuş kurt yemezse bir sonraki sene verim olmaz.

- Gereksiz yere makas açık bırakılmaz, eğer bırakılırsa o eve bir bela geleceğine inanilir.

- Kazayı, belayı, ölüme de götürebilen musibetleri gidermek için yeni alınmış arabanın önünde ve inşaatın temelinde kurban kesilir.

- Çok gülünce başına bir kötülük geleceğine inanılır. inanilir.

- Yerde yatan bir kişinin üzerinden geçilirse, yatan kişinin boyunun kısalacağına 


\section{DEĞERLENDİRME}

Kale-Davaz bölgesinde görülen inanç ve uygulamaların başında türbeler gelmektedir. Türbeler Anadolu'nun ve diğer Türk coğrafyalarının birçok yerinde karşımıza çıkmaktadır. Toplumun kutsal olarak atfettiği şahsiyetler, öldükten sonra da kutsallığını korumuş ve birçok yönden onlar etrafinda "inanç ve uygulamalar" meydana gelmiştir. Bu kutsal şahsiyetler, İslamiyet öncesi Türk kültüründe ozan-baksı-kam gibi adlarla anılan ve toplumun belleğinde "Tanrı ile aracı olarak" yer edinen kişiler olarak; İslamiyet ile birlikte ise "veli-eren-dedebaba-evliya" gibi adlarla yaşamaya devam etmişlerdir. Türk kültürel belleğine ilişkin "ağaç, dağ, tepe, ata" gibi temel kodların veli-eren tipleri üzerinden anlatılan efsanelerde ve bu şahsiyetlerin bulunduğu türbeler etrafındaki uygulamalarda karşılaşıldığı söylenebilir. Bahsedilen türbeler arasında "Kuş Dede", "Arap Apıştı" ve "Yaren Baba" türbelerinin yüksek yerde olması, dağ-tepe kültüyle ilişkilidir. Eski Türklerde insanüstü varlıkların ve ruhların mekânı olarak ifade edilen dağlar ve tepeler, İslamiyet ile birlikte veli-eren gibi şahsiyetlerin bu mevkide olması toplumsal algının devamlılığında bir değişmenin olmadığını göstermektedir. Diğer türbelerden "Koyun Baba Türbesi" ve "Yaren Baba Türbesi" kurban kesme, adak adama gibi birtakım ritüellerin gerçekleşmesinde gidilen yerler olarak görülmektedir. $\mathrm{Bu}$ açıdan kutsallık atfedilen kişilerin bulunduğu mekânın da kutsal olması sebebiyle, sunulan kurban ve adak ritüellerinin bu mekânlarda uygulanması adı geçen şahsiyetlerin Allah'a yakın olmasıyla açıklanabilir. Dolayısıyla, duaların, kurbanların, adakların; çocuksuzluğa ve hastalıklara çare aranması gibi uygulamaların veli-eren-evliya adı verilen şahsiyetlerin türbeleri etrafında gerçekleştirilmesi, bu şahsiyetlerin Allah'a yakın ve keramet sahibi olmaları gibi işlevlere sahip olmasından kaynaklandığını ve adı geçen şahsiyetlerin eski Türk inanç sistemi içinde "atalar kültü"nün bir yansıması ya da uzantısı olduğu söylenebilir.

Kala-Davaz bölgesinde, hayatın üç önemli geçiş dönemi olan "doğum-evlenme ve ölüm”le ilgili inanç ve uygulamalarda da Türk kültür çevresindeki ortak algının izlerini görmek mümkündür. Örneğin, eski Türk inancinda "albastı", "alkarası" olarak bilinen bir ruhun çocuklara zarar verdiği bilinmektedir. Buna karşı kırmızı renkli bir nesnenin kullanılması Türk coğrafyasında görülen yaygın bir inanıştır. Dolayısıyla Kale-Davaz bölgesinde de bu uygulamanın görülmesi Türk ortak kültürel belleğindeki süreklilikten kaynaklanmaktadır.

Günlük yaşamda, halkın kötü ruhlardan ve nazardan korunmak için birtakım inanç ve uygulamalar gösterdikleri tespit edilmiştir. $\mathrm{Bu}$ inançların temelinde de eski Türk inanç dizgesinin izleri olduğu söylenebilir. Eşiğe oturmanın hoş karşılanmaması, ölünün yanında tütsü yakılması, dünyanın öküzün boynuzu üzerinde durması, loğusa kadının yanına demirden yapılmış herhangi bir maddenin konulması gibi inançların Türk ortak kültürel belleğinde korunarak günümüze kadar aktarıldığı görülmektedir.

Sonuç olarak, Kale-Davaz bölgesinde görülen halk inançları ve uygulamalarını, genel olarak Türkistan coğrafyasında; özel olarak Anadolu coğrafyasındaki inanç ve uygulamalarla benzerlik gösterdiği söylenebilir. 


\section{REFERENCES}

- Acipayamlı, Orhan (1963), Türkiye'de Yağmur Duası, DTCF Dergisi, c. XXI. S. 1-2, l-39.

- Arslan, Mustafa, AKARPINAR, R. Bahar (2010), Türk Halk Edebiyatı El Kitabı, Ankara: Grafiker Yayınları.

- Assmann, Jan (2001), Kültürel Bellek, İstanbul: Ayrıntı Yayınları.

- Barkan, Ömer Lütfi (1942), Kolonizatör Türk Dervişleri, Vakıflar Dergisi II.

- Bingöl, Süleyman (1997), Jean Paul Roux’un Eserlerinde Türk Gelenek ve Görenekleri, Basılmamış Yüksek Lisans Tezi, Pamukkale Üniversitesi SBE. Denizli.

- Boratav, Pertev Naili (1997), 100 Soruda Türk Folkloru, İstanbul: Gerçek Yayınevi.

- Çakmakçı, Emin (2011), Kaynak Kişi. Kurubağlık Köyü.

- Çetin, İsmet (2007), Türk Kültürün Bab (Baba)/ Ata Geleneği, Milli Folklor Uluslar Aras1 Halkbilimi Dergisi, S. 76, 70-75.

- Çobanoğlu, Özkul (2003), Türk Halk Kültüründe Memoratlar ve Halk İnançları, Ankara: Akçağ Yayınları.

- Eliade, Mircea (1999), (Çev. İsmail BİRKAN), Şamanizm, İstanbul: İmge Yayınevi.

- Ergin, Muharrem (2004), Dede Korkut Kitabı I, Ankara: TDK Yayınları.

- Ergun, Pervin (2004), Türk Kültüründe Ağaç Kültü, Ankara: AKM Yayınları.

- Günay, Ünver, GÜNGÖR, Harun vd. (2001), Ziyaret Fenomeni Üzerine Bir Din Bilimi Araştırması, Kayseri: Erciyes Üniversitesi Yayınları.

- İnan, Abdülkadir (2006), Tarihte ve Bugün Şamanizm Materyaller ve Araştırmalar, Ankara: TTK Yayınları.

- Kahraman, S. Ali (2013). Günümüz Türkçesiyle Evliya Çelebi Seyahatnamesi - 2, 710. Kitaplar, Dizin, İstanbul: 2013.

- Kökçıkaran, Fatma (2011), Kaynak Kişi. Yeniköy Köyü.

- Mete, Hakan Sinan (1996), "Hamza Baba Türbesi Etrafinda Oluşmuş Halk İnançları”, Türk Halk Kültürü Araştırmaları, Ankara: Kültür Bakanlığı Yayınları.

- Ocak, Ahmet Yaşar (2010), Alevi-Bektaşi İnançlarının İslam Öncesi Temelleri, İstanbul: İletişim Yayınevi.

- Oğuz, M. Öcal (2011), "Çok Mekanlı ve/veya Çok Mezarlı Anlatı Kahramanları: Yunus Emre”, Milli Folklor Uluslararası Halkbilimi Dergisi, S. 91, 5-11.

- Ögel, Bahaeddin (1995), Türk Mitolojisi II, Ankara: TTK Yayınları.

- Önal, M. Naci (2000), "Romanya Doburcasında Yedi Türbe", Türk Halk Kültürü Araştırmaları, Ankara: Kültür Bakanlığı Yayınları.

- Pekçok, Kamil (2011), Kaynak Kişi. İnceğiz Köyü.

- Yarımca, İsmail (2011), Kaynak Kişi. Kale İlçesi. 